\title{
Xylan oligosaccharides and cellobiohydrolase I (TrCel7A) interaction and effect on activity
}

Martin J Baumann ${ }^{1,2}$, Kim Borch $^{2}$ and Peter Westh ${ }^{1^{*}}$

\begin{abstract}
Background: The well-studied cellulase mixture secreted by Trichoderma reesei (anamorph to Hypocrea jecorina) contains two cellobiohydolases (CBHs), cellobiohydrolase I (TrCel7A) and cellobiohydrolase II (TrCel6A), that are core enzymes for the solubilisation of cellulose. This has attracted significant research interest because of the role of the $\mathrm{CBHs}$ in the conversion of biomass to fermentable sugars. However, the CHBs are notoriously slow and susceptible to inhibition, which presents a challenge for the commercial utilisation of biomass. The xylans and xylan fragments that are also present in the biomass have been suggested repeatedly as one cause of the reduced activity of CHBs. Yet, the extent and mechanisms of this inhibition remain poorly elucidated. Therefore, we studied xylan oligosaccharides (XOSs) of variable lengths with respect to their binding and inhibition of both TrCel7A and an enzyme variant without the cellulose-binding domain (CBM).

Results: We studied the binding of XOSs to TrCel7A by isothermal titration calorimetry. We found that XOSs bind to TrCel7A and that the affinity increases commensurate with XOS length. The CBM, on the other hand, did not affect the affinity significantly, which suggests that XOSs may bind to the active site. Activity assays of $\operatorname{TrCel7A}$ clearly demonstrated the negative effect of the presence of XOSs on the turnover number.

Conclusions: On the basis of these binding data and a comparison of XOS inhibition of the activity of the two enzyme variants towards, respectively, soluble and insoluble substrates, we propose a competitive mechanism for XOS inhibition of TrCel7A with phosphoric swollen cellulose as a substrate.
\end{abstract}

Keywords: cellobiohydrolase 1, TrCel7A, xylan, xylan oligosaccharide, binding, inhibition, biomass degradation, isothermal titration calorimetry

\section{Background}

Biomass is the most abundant raw material in the biosphere, and enzymatic biomass conversion of sugars and subsequent fermentation to transportation fuels has attracted enormous scientific and industrial interest [1]. In typical biomass raw materials such as corn stover or wheat straw, cellulose is not present in pure form but is in close contact with hemicelluloses such as xylan, mannan and xyloglucan and encrusted with lignin [2]. Many thermochemical pretreatments have been developed to disperse and dissolve the recalcitrant complex to make it more easily accessible for enzymatic hydrolysis [3].

Several phenomenological studies have documented a negative influence of xylans and xylan oligosaccharides

\footnotetext{
* Correspondence: pwesth@ruc.dk

'Research Unit for Biomaterials, Roskilde University, NSM, Universitetsvej 1,

DK-4000, Roskilde, Denmark

Full list of author information is available at the end of the article
}

(XOSs) on the performance of industrial cellulase mixtures [4-7]. However, which enzymes of the commercial cellulases are affected remains unresolved. Furthermore, target sites and mechanisms of these effects remain to be investigated. Such information will clearly be needed when considering remedies for xylan inhibition.

The term 'cellulase' most often refers to secreted cellulolytic enzymes of fungal origin. For instance, the cellulases secreted by Trichoderma reesei (anamorph to Hypocrea jecorina) contain several endoglucanases and two cellobiohydrolases (CBHs) which process exo-acting, cellobiose-releasing enzymes. The $\mathrm{CBHs}$ exhibit quite low reaction rates and non-Michaelis-Menten kinetics, which include an initial burst followed by a biphasic slowdown $[8,9]$. Classical inhibition studies which result in an inhibition constant $K_{\mathrm{i}}$ are not applicable to cellobiohydrolases, because the concentration of the insoluble substrate cellulose is very difficult to measure and,
C Biomed Central

() 2011 Baumann et al; licensee BioMed Central Ltd. This is an Open Access article distributed under the terms of the Creative Commons Attribution License (http://creativecommons.org/licenses/by/2.0), which permits unrestricted use, distribution, and reproduction in any medium, provided the original work is properly cited. 
as mentioned above, steady-state reaction kinetics are absent. In industrial batch hydrolysis of biomass $\mathrm{CBHs}$ can suffer from product inhibition, which is partially reduced through the cellobiase activity of added $\beta$-glucosidases $[9,10]$. Traditionally, CBHs have been claimed to require free chain ends as starting points and free cellulose chain ends are in turn generated by endoglucanases, which hydrolyse the cellulose chain randomly in endo-fashion. However, this strict classification has been challenged by the demonstration of endo-attack by $\mathrm{CBHs}$ and processive action of endoglucanases [11].

Cellobiohydrolase I ( $\operatorname{TrCel7A}$ ) is the most abundant enzyme secreted by Trichoderma reesei. It is a modular $52 \mathrm{kDa}$ enzyme with a catalytic domain (GH7) [12] and a family 1 cellulose binding domain (http://www.cazy. org/), which are interconnected by a highly glycosylated linker $[13,14]$. The catalytic domain has a tunnel-shaped active site with ten subsites [14].

In this study, we investigated the apparent inhibition of $\operatorname{TrCel7A}$ by xylan products in a model system with XOSs, which are enzymatically derived from birch wood xylan. $\operatorname{TrCel7A}$ is used in two variants, the full-length enzyme $(\operatorname{Tr}$ Cel7A) and the catalytic domain only ( $\operatorname{TrCel7A}$ core). The influence of the degree of polymerisation (DP) of XOS ligand binding was tested by performing isothermal titration calorimetry (ITC). Activity measurements of TrCel7A were conducted with paranitrophenyl- $\beta$-D-lacoside ( $p$ NP-lac) or phosphoric acid swollen cellulose (PASC) in the presence of XOS pools of different DPs.

\section{Results}

The interaction of XOSs with $\operatorname{TrCel7A}$ was investigated using two approaches: ITC binding experiments and activity measurements. The activity measurements were carried out on PASC and/or $p$ NP-lac in the presence of enzymatically prepared mixed XOSs. These measurements require large amounts of XOS (gram-scale) which were not available from the purification of XOSs by size exclusion chromatography. To investigate the influence of the average molecular mass, XOS was split into two fractions by ethanol precipitation. Low-molecular-mass XOS (low XOS) and high-molecular-mass XOS (high XOS) have an average of 4.0 or 8.1 DP xylose units, respectively (Figure 1).

We chose to assess $\operatorname{Tr}$ Cel7A activity in the presence of XOS using two different assay methods. First, a small chromogenic lactose, $p$ NP-lac, was used in a straightforward stopped assay to assess the activity of $\operatorname{TrCel7A}$ [15]. $p$ NP-lac activity has been used by Jalak and Välijamäe [16] to measure the portion of $\operatorname{Tr} C$ el7A that has a free, unoccupied active site. The specific activity of $\operatorname{TrCel7A}$ for $p$ NP-lac in our study was approximately a factor of 10 lower than that for PASC (Table 1).

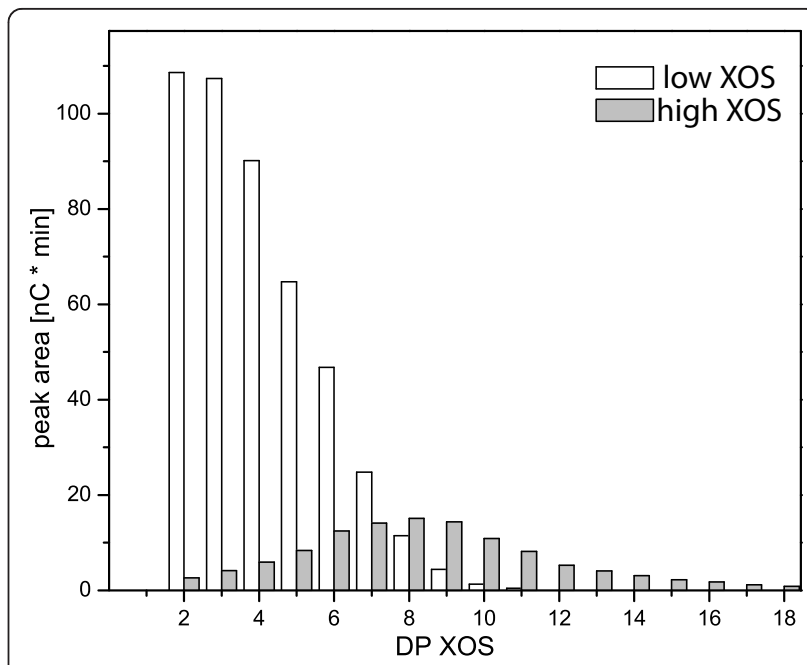

Figure 1 HPAEC-PAD analysis of $1 \mathrm{~g} / \mathrm{L}$ low xylan oligosaccharide and $1 \mathrm{~g} / \mathrm{L}$ high xylan oligosaccharide. Highperformance anion-exchange chromatography with pulsed amperometric detection (HPAEC-PAD) analysis of low xylan oligosaccharide (XOS, open columns) and high XOS (grey columns).

The peak from xylobiose to xylopentose was identified by comparison with commercially available XOSs, and longer oligosaccharides were named accordingly. The peak areas of $10 \mu \mathrm{L}$ of $5 \mathrm{~g} / \mathrm{L}$ solutions are shown. The response factors for xylobiose to xylopentose were between 0.09 and 0.1 and were almost constant. The average degree of polymerisation (DP) (by peak area) of low XOS was $4.0,80 \%$ between $(x y l)_{2}$ and $(x y l)_{6}$ and $90 \%$ between $(x y l)_{2}$ and $(x y l)_{7}$; the average DP of high XOS was $8.1,80 \%$ between $(x y l)_{5}$ and $(x y \mid)_{13}$ and $90 \%$ between $(x y l)_{3}$ and $(x y \mid)_{13}$.

We used a second approach to measure $\operatorname{TrCel7A}$ activity in which we quantified the cellobiose release from PASC by high-performance anion-exchange chromatography with pulsed amperometric detection (HPAEC-PAD). Typical Cel7A assays include cellobiase (for example, $\beta$-glucosidase) to avoid product inhibition, but many $\beta$-glucosidases show activity on nitrophenyl xyloside [17-19] and may also have activity on XOS, which might obfuscate the activity data of the current inhibition studies. To dissect the mechanism of $\operatorname{TrCel7A-inhibition~by~XOS~further,~we~used~the~modu-~}$ larity of the enzyme to test the influence of the CBM on activity in the presence of XOS. We used two variants

Table 1 Specific activities of $\operatorname{TrCel7A}$ and $\operatorname{TrCel7A}$ core at $50^{\circ} \mathrm{C}$ per hour

\begin{tabular}{lll}
\hline Enzyme & Substrate & $\boldsymbol{k}_{\text {cat }}$ \\
\hline TrCel7A & PASC $(1 \mathrm{~g} / \mathrm{L})$ & $0.44 /$ second \\
TrCel7A core & PASC $(1 \mathrm{~g} / \mathrm{L})$ & $0.24 /$ second \\
TrCel7A & PNP-lac $(0.5 \mathrm{mM})$ & $0.07 /$ second \\
TrCel7A core & pNP-lac $(0.5 \mathrm{mM})$ & $0.06 /$ second \\
\hline
\end{tabular}

$k_{\text {cat }}=$ catalytic constant; PASC $=$ phosphoric acid swollen cellulose; $p$ NP-lac $=$ para-nitrophenyl- $\beta$-D-lacoside; $\operatorname{TrCel7A}=$ cellobiohydrolase I. 
of $\operatorname{TrCel7A}$, the full-length enzyme and the $\operatorname{TrCel7A}$ core $(\operatorname{TrCel7A}$ truncated on DNA level by the linker and the CBM), which allowed us to study the influence of the CBM on XOS inhibition.

ITC isotherms at $30^{\circ} \mathrm{C}$ for both purified and mixed $\mathrm{XOSs}$ were readily analysed using standard binding models provided by the MicroCal/GE Healthcare, (Northampton, MA, USA) instrument manufacturer (Figure 2). At $50^{\circ} \mathrm{C}$, the signals were small and the quality of the data did not allow regression analysis. This most likely reflects the binding enthalpies becoming smaller at the higher temperature, hence ITC was not a suitable experimental method. The binding constants at $30^{\circ} \mathrm{C}$ increased from about $10^{3}$ for the trisaccharide to over $10^{5}$ for a XOS mixture with a $1: 1: 1$ ratio (8 DP, $9 \mathrm{DP}$ and $10 \mathrm{DP}$ ) (Table 2). Table 2 also shows that both enzyme variants had similar affinity for XOS. To study the interaction of $\operatorname{TrCel7A}$ and $\mathrm{XOS}$, we measured the binding of pure linear XOSs to $\operatorname{TrCel7A}$ by ITC. The binding constants increased strongly with chain lengths of the XOS (Table 1). A typical example of the binding isotherms obtained is shown in Figure 2.

\section{TrCel7A hydrolytic activity on pNP-lac}

$p$ NP-lac was used as a small model substrate for Cel7A [14-16,20]. The effect of low XOS and high XOS was tested with $p$ NP-lac as the substrate (Table 3 ). The addition of $1 \mathrm{~g} / \mathrm{L}$ low XOS reduced the remaining activity to $21 \%$ or $15 \%$ for $\operatorname{TrCel7A}$ core or $\operatorname{TrCel7A}$, respectively. The addition or $1 \mathrm{~g} / \mathrm{L}$ high XOS removed $90 \%$ of the control $p$ NP-releasing activity. In these experiments, the control activity $\operatorname{TrCel7A}$ and $\operatorname{TrCel7A}$ core did not differ substantially, indicating that the presence of the CBM had little or no effect on the activity on the soluble, small-molecule $p$ NP-lac. Dose-response curves were generated for $\operatorname{TrCel7} \mathrm{A}$ at $50^{\circ} \mathrm{C}$ (Figure 3). The curve for high XOS declined more sharply at lower concentrations than the inactivation curve of low XOS. This demonstrates the relatively greater importance of molecular length (high XOS vs low XOS) over the molecular concentrations of XOS.

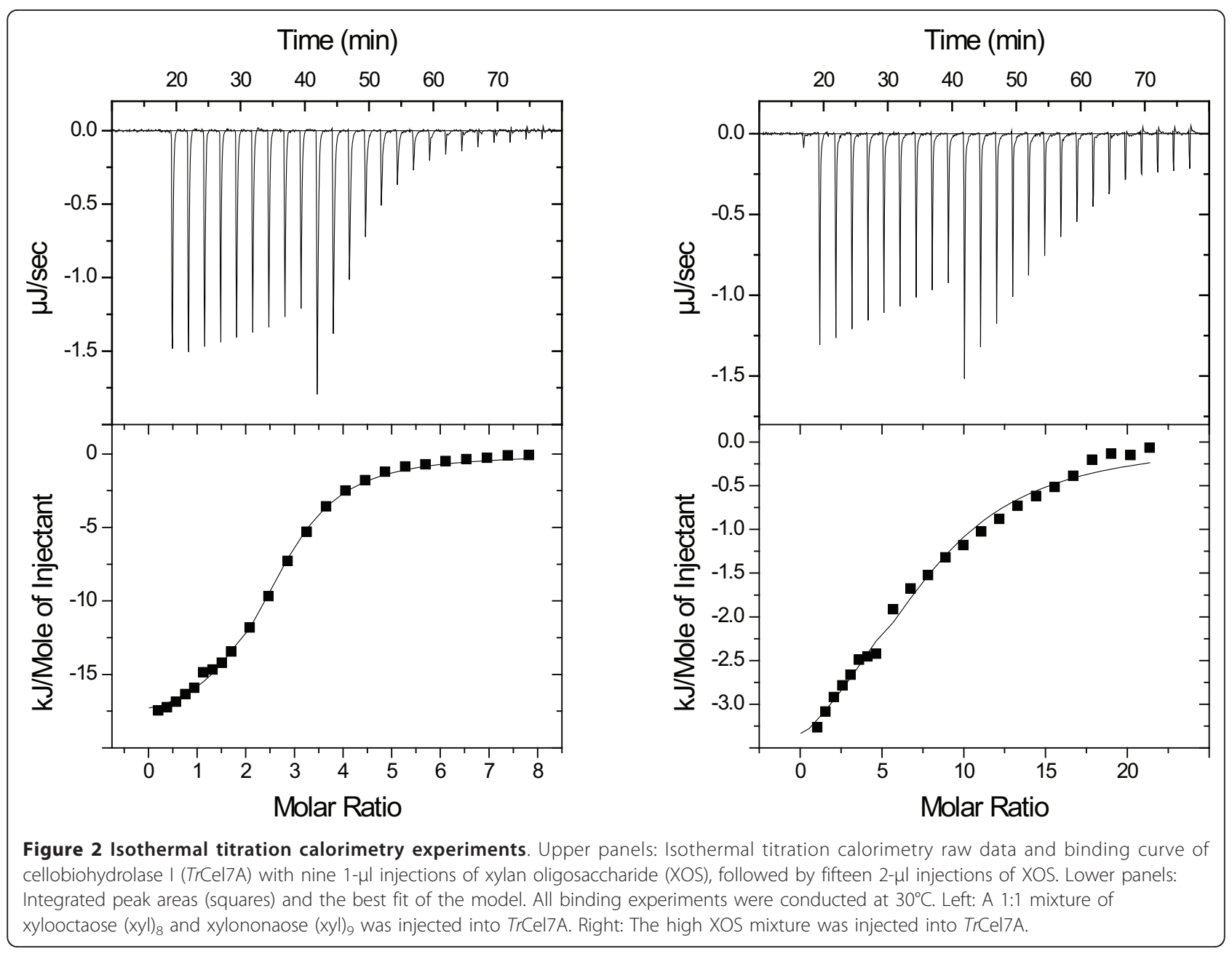


Table 2 Binding constants based on a molar concentration scale of TrCel7A and TrCel7A core to linear xylan oligosaccharides

\begin{tabular}{|c|c|c|}
\hline Xylan oligosaccharide & $\operatorname{TrCel7A}$ core $(K)$ & $\operatorname{TrCel7A}(K)$ \\
\hline $\begin{array}{l}\text { Xylotriose }(x y l)_{3} \\
\end{array}$ & $>1.0 \times 10^{3}$ & - \\
\hline Xylotetraose $(x y l)_{4}$ & $2.97 \times 10^{3}$ & - \\
\hline Xylohexaose $(x y l)_{5}$ & $3.44 \times 10^{3}$ & $3.44 \times 10^{3}$ \\
\hline Xyloheptaose $(x y l)_{7}$ & $7.43 \times 10^{3}$ & $5.76 \times 10^{3}$ \\
\hline Xylooctaose/xylononaose, $(x y \mid)_{8} /(x y l)_{9}(1: 1)$ & $1.19 \times 10^{4}$ & $9.20 \times 10^{4}$ \\
\hline Xylooctaose/xylononaose/xylodecaose, $(x y \mid)_{8} /(x y l)_{9} /(x y l)_{10}(1: 1: 1)$ & $2.91 \times 10^{5}$ & - \\
\hline Low XOS $(5 \mathrm{~g} / \mathrm{L} \text { and } 8.4 \mathrm{mM} \text {, average } 4 \mathrm{DP})^{\mathrm{a}}$ & $7.18 \times 10^{2}$ & $9.13 \times 10^{2}$ \\
\hline High XOS $(5 \mathrm{~g} / \mathrm{L} \text { and } 4.4 \mathrm{mM} \text {, average } 8 \mathrm{DP})^{\mathrm{a}}$ & $4.57 \times 10^{3}$ & $3.47 \times 10^{3}$ \\
\hline
\end{tabular}

$\mathrm{DP}=$ degree of polymerisation; $\operatorname{TrCel7A}=$ cellobiohydrolase $\mathrm{I}$; XOS = xylan oligosaccharide; - = no data. ${ }^{\mathrm{a}}$ Estimated on the basis of high-performance anionexchange chromatography with pulsed amperometric detection traces and binding experiments $(n=3)$.

Hydrolytic activity on PASC in the presence of pNP-lac $\operatorname{TrCel7A}$ activities were evaluated with PASC in the presence of $p$ NP-lac substrate (Table 3 ). Control experiments revealed that the presence on $1 \mathrm{mM} p \mathrm{NP}$-lac changed the release of cellobiose by $10 \%$ (Table 4 ), which for most of the samples was within the standard deviation. The specific activity of $\operatorname{TrCel7A}$ on PASC was twice as high as that of $\operatorname{TrCel7A}$ core. (Table 1) The susceptibility to XOS inhibition of $\operatorname{TrCel7A}$ and $\operatorname{TrCel7A}$ core on PASC differed widely. Low XOS practically did not change the activity of $\operatorname{TrCel7A}$, and $\operatorname{TrCel7A}$ core produced only $60 \%$ of the cellobiose in the presence of low XOS. High XOS reduced the activity of both tested $\operatorname{TrCel7A}$ variants. Full-length $\operatorname{TrCel7A}$ activity produced $80 \%$ of the cellobiose, and $\operatorname{TrCel} 7 \mathrm{~A}$ core activity was reduced to values close to $50 \%$ of the cellobiose produced without added XOS.

\section{TrCel7A hydrolytic activity on pNP-lac in the presence of PASC}

The activity of unbound $\operatorname{Tr}$ Cel7A and $\operatorname{Tr}$ Cel7A core in the presence of PASC was followed by $p$ NP-lac hydrolytic activity (Table 5 ). The $p$ NP-lac hydrolytic activity of $\operatorname{TrCel7A}$ and $\operatorname{TrCel7A}$ core was, respectively, $7 \%$ and $20 \%$ of the total activity against $p$ NP-lac observed in the absence of PASC (Table 5). This indicates that 93\% or $80 \%$, respectively, of the $\operatorname{Tr}$ Cel7 A or $\operatorname{TrCel7A}$ core active sites are not available for $p$ NP-lac hydrolysis. The addition of low XOS and high XOS further reduced $p$ NP-lac hydrolytic activity. Again, as we observed with regard to cellulolytic activity on PASC, high XOS produced a greater reduction of $p \mathrm{NP}$-lac activity than low XOS did. Because the $p$ NP-lac activity of $\operatorname{TrCel7A}$ in the presence of PASC was already reduced to $7 \%$ of the initial $p \mathrm{NP}$-lac activity, further reductions in $p \mathrm{NP}$-lac activity induced by the addition of XOS could not be quantified. The fractional decrease in $p \mathrm{NP}$-lac activity brought about by PASC was larger at $30^{\circ} \mathrm{C}$ than at $50^{\circ} \mathrm{C}$, which indicates that more enzyme may be bound at the lower temperature.

\section{Discussion}

We tested the effect of XOSs on the activity of two TrCel7A variants in samples with PASC, $p$ NP-lac or both. The binding affinity of XOS with known DP was also quantified for both enzyme variants. The combined interpretation of the binding and activity data suggests that XOS binds to the active site of TrCel7A and hence exerts competitive inhibition. Moreover, our results suggest that the affinity for the active site follows the

Table 3 Para-nitrophenyl release of $\operatorname{TrCel7A}$ and $\operatorname{TrCel7A}$ core from $p N P$-lac as a single substrate at $50^{\circ} \mathrm{C}$ and $30^{\circ} \mathrm{C}^{\mathrm{a}}$

\begin{tabular}{|c|c|c|c|}
\hline $\begin{array}{l}\text { Enzyme (temperature } \\
\text { substrate) }\end{array}$ & Activity in 1 hour & Activity in 1 hour (1 g/L low XOS) & Activity in 1 hour (1 $\mathrm{g} / \mathrm{L}$ high XOS) \\
\hline $\operatorname{TrCel7A}$ core, $50^{\circ} \mathrm{C}$ & $\begin{array}{l}127 \pm 5 \mu \mathrm{M} p \mathrm{NP}^{\mathrm{b}} \\
436 \pm 11 \mu \mathrm{M} \mathrm{cb}^{\mathrm{b}}\end{array}$ & $\begin{array}{l}21 \% \pm 4 p N P \\
61 \% \pm 6 c b\end{array}$ & $\begin{array}{l}10 \% \pm 2 p N P \\
44 \% \pm 2 c b\end{array}$ \\
\hline $\operatorname{TrCel7A}, 50^{\circ} \mathrm{C}$ & $\begin{array}{l}99 \pm 3 \mu \mathrm{M} p N P \\
695 \pm 32 \mu \mathrm{M} \mathrm{cb}\end{array}$ & $\begin{array}{l}15 \% \pm 2 p N P \\
96 \% \pm 4 c b\end{array}$ & $\begin{array}{l}9 \% \pm 1 p N P \\
81 \% \pm 5 \mathrm{cb}\end{array}$ \\
\hline $\operatorname{TrCel7A}$ core, $30^{\circ} \mathrm{C}$ & $\begin{array}{l}50 \pm 2 \mu \mathrm{M} p N P \\
177 \pm 6 \mu \mathrm{M} \mathrm{cb}\end{array}$ & $\begin{array}{l}21 \% \pm 2 p N P \\
61 \% \pm 7 c b\end{array}$ & $\begin{array}{l}10 \% \pm 4 p N P \\
55 \% \pm 4 \mathrm{cb}\end{array}$ \\
\hline $\operatorname{TrCel7A}, 30^{\circ} \mathrm{C}$ & $\begin{array}{l}38 \pm 1 \mu \mathrm{M} p \mathrm{NP} \\
204 \pm 10 \mu \mathrm{M} \mathrm{cb}\end{array}$ & $\begin{array}{l}15 \% \pm 3 p N P \\
96 \% \pm 2 c b\end{array}$ & $\begin{array}{l}9 \% \pm 3 p N P \\
81 \% \pm 2 c b\end{array}$ \\
\hline
\end{tabular}

cb: cellobiose-solubilised; $p N P=$ para-nitrophenyl release; $p$ NP-lac = para-nitrophenyl- $\beta$-D-lacoside; $\operatorname{TrCel7A}=$ cellobiohydrolase ; XOS = xylan oligosaccharide. ${ }^{a}$ The cellobiose release from phosphoric acid swollen cellulose (PASC) in the presence of $p$ NP-lac by $\operatorname{TrCel7A}$ and $\operatorname{TrCel7A}$ core at $50^{\circ} \mathrm{C}$ and $30^{\circ} \mathrm{C}$ was measured in separate experiments. The deviations are the standard deviations of five independent experiments. ${ }^{\mathrm{b}}$ The cellobiose release from PASC was independent of $p$ NPlac (Table 4). 


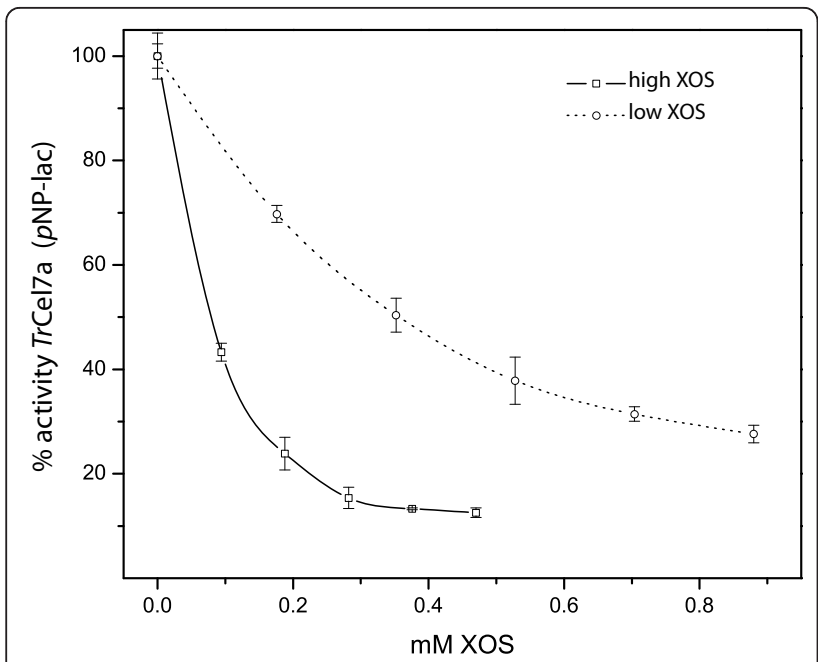

Figure 3 Inhibitory effects of xylan oligosaccharide on the para-nitrophenyl-lac activity of $\operatorname{TrCel7A}$. The inhibitory effects of high xylan oligosaccharide (XOS) (open squares) and low XOS (open circles) on the para-nitrophenyl-lacoside ( $p N P$-lac) hydrolytic activity of cellobiohydrolase I (TrCel7A) at $50^{\circ} \mathrm{C}$ are shown. The molarities based on the estimates measured by high-performance anionexchange chromatography with pulsed amperometric detection analysis (see Figure 1), $0.5 \mathrm{~g} / \mathrm{L}$ high XOS and $0.5 \mathrm{~g} / \mathrm{L}$ low XOS, were estimated to be $0.47 \mathrm{mM}$ and $0.88 \mathrm{mM}$, respectively. The error bars represent the standard deviations of three experiments.

sequence PASC $>$ XOS $>p$ NP-lac and consequently that $\mathrm{XOS}$ is a much stronger inhibitor of $p$ NP-lac hydrolysis than of PASC hydrolysis. Next we discuss arguments for and aspects of this proposed mechanism of XOS inhibition.

With $p$ NP-lac alone (Table 3), the specific activities of $\operatorname{TrCel7A}$ and $\operatorname{Tr}$ Cel7A core were essentially the same and the addition of low XOS or high XOS resulted in severe and similar activity loss for both enzymes. Hence the CBM does not play a role for the small, soluble substrate analog $p$ NP-lac. These observations and the strong affinity of XOS observed for both enzyme variants suggest that XOS bind more strongly than $p$ NP-lac and hence inhibits their activity. The inhibition by XOSs was much less pronounced when PASC was used as the substrate. In fact, the intact enzyme was not detectably inhibited by low XOS (Table 4). This difference most likely reflects the higher binding affinity of PASC strands to the catalytic domain of $\operatorname{TrCel} 7$ compared to the binding of $p$ NP-lac to the $\operatorname{TrCel7A}$ catalytic domain. An analogous relationship was measured with cellobiose as a competitive inhibitor. The reported $K_{\mathrm{i}}$ value for cellobiose with $p \mathrm{NP}-\mathrm{lac}$ is $20 \mu \mathrm{M}$ [20], and for bacterial cellulose it is approximately 50 times higher at around 1 $\mathrm{mM}$ [21]. This hypothesis is also in line with the observation that high XOS, despite the lower molar concentration $(1 \mathrm{~g} / \mathrm{L}$ equals about $4 \mathrm{mM})$, was caused greater inhibition than low XOS ( $1 \mathrm{~g} / \mathrm{L}$ equals about $8 \mathrm{mM})$ (Table 3 and Figure 3). This can be simply explained by the higher binding affinity (Table 2) of high XOS, which overcompensates the lower molarity of high XOS.

Using PASC as a substrate, we observed that the presence of the CBM in $\operatorname{TrCel7A}$ plays a more prominent role in the sensitivity to XOS inhibition. The $p$ NP-lac measurements in the presence of PASC showed that at most $7 \%$ of the added $\operatorname{Tr}$ Cel7A had an accessible active site. Thus we concluded that the missing 93\% $p$ NP-lac activity is removed by binding of $T r C e l 7 \mathrm{~A}$ to PASC, followed by occupation of the active site by a cellulose strand. The $\operatorname{TrCel7A}$ variant without CBM showed an increased $p$ NP-lac activity (20\% of the added activity is free in the buffer, when compared with the full length enzyme. This indicates that the presence of the CBM decreases the probability of a free active site in the presence of PASC. Our results derived from the two measurements combined gives a strong indication of the mechanism of activity inhibition of $\operatorname{TrCel7A}$ by XOSs. In a hydrolytic reaction, more than $80 \%$ of $\operatorname{TrCel} 7 \mathrm{~A}$ is bound to the substrate (Table 5). The presence of the $\mathrm{CBM}$ changed the equilibrium between free and bound $\operatorname{TrCel7A}$ from $20 \%$ free to less than $10 \%$ free in our experiments. This shift was even more pronounced at $30^{\circ} \mathrm{C}$ than at $50^{\circ} \mathrm{C}$. The presence of the family $1 \mathrm{CBM}$ in $\operatorname{Tr}$ Cel7A plays a pivotal role in its location and thereby

Table 4 Cellobiose release from phosphoric acid swollen cellulose by $\operatorname{TrCel7A}$ and $\operatorname{TrCel7A}$ core at $50^{\circ} \mathrm{C}$ and $30^{\circ} \mathrm{C}$

\begin{tabular}{llll}
\hline Enzyme (temperature substrate) & Positive control & $\mathbf{1} \mathbf{~ g / L ~ l o w ~ X O S}$ & $\mathbf{1} \mathbf{~ g / L ~ h i g h ~ X O S ~}$ \\
\hline TrCel7A core, $50^{\circ} \mathrm{C}$ & $457 \pm 10 \mu \mathrm{M} \mathrm{cb}$ & $260 \pm 19 \mu \mathrm{M} \mathrm{cb}$ & $196 \pm 3 \mu \mathrm{M} \mathrm{cb}$ \\
PASC & $100 \%$ & $57 \%$ & $43 \%$ \\
$\operatorname{TrCel7A}, 50^{\circ} \mathrm{C}$ & $695 \pm 65 \mu \mathrm{M} \mathrm{cb}$ & $611 \pm 60 \mu \mathrm{M} \mathrm{cb}$ & $587 \pm 57 \mu \mathrm{M} \mathrm{cb}$ \\
PASC & $100 \%$ & $88 \%$ & $85 \%$ \\
$\operatorname{TrCel7A}$ core, $30^{\circ} \mathrm{C}$ & $183 \pm 7 \mu \mathrm{M} \mathrm{cb}$ & $111 \pm 8 \mu \mathrm{M} \mathrm{cb}$ & $87 \pm 5 \mu \mathrm{Mcb}$ \\
PASC & $100 \%$ & $61 \%$ & $48 \%$ \\
TrCel7A, $30^{\circ} \mathrm{C}$ & $194 \pm 8 \mu \mathrm{M} \mathrm{cb}$ & $194 \pm 4 \mu \mathrm{M} \mathrm{cb}$ & $196 \pm 1 \mu \mathrm{Mcb}$ \\
PASC & $100 \%$ & $96 \%$ & $100 \%$ \\
\hline
\end{tabular}

cb: cellobiose-solubilised; PASC = phosphoric acid swollen cellulose; TrCel7A = cellobiohydrolase $\mathrm{l} ; \mathrm{XOS}=$ xylan oligosaccharide. The deviations are the standard deviations of five independent experiments. 
Table 5 Para-nitrophenyl release by $\operatorname{TrCel7A}$ or $\operatorname{TrCel7A}$ core from $p N P$-lac at $50^{\circ} \mathrm{C}$ and $30^{\circ} \mathrm{C}$ in the presence of phosphoric acid swollen cellulose

\begin{tabular}{|c|c|c|c|}
\hline Enzyme, temperature substrate & Control & $1 \mathrm{~g} / \mathrm{L}$ low XOS & $1 \mathrm{~g} / \mathrm{L}$ high XOS \\
\hline $\begin{array}{l}\operatorname{TrCel7A} \text { core, } 50^{\circ} \mathrm{C} \\
p \text { NP-lac }{ }^{\mathrm{a}} \text { (PASC) }\end{array}$ & $\begin{array}{l}25 \pm 2 \mu \mathrm{M} p \mathrm{pNP} \\
20 \% \text { of total activity }\end{array}$ & $\begin{array}{l}15 \pm 4 \mu \mathrm{M} p \mathrm{NP} \\
12 \% \text { of total activity }\end{array}$ & $\begin{array}{l}9 \pm 1 \mu \mathrm{M} p \mathrm{NP} \\
8 \% \text { of total activity }\end{array}$ \\
\hline $\begin{array}{l}\operatorname{TrCel7A}, 50^{\circ} \mathrm{C} \\
\text { pNP-lac (PASC) }\end{array}$ & $\begin{array}{l}6 \pm 1 \mu \mathrm{M} p \mathrm{NP} \\
7 \% \text { of total activity }\end{array}$ & $\begin{array}{l}5 \pm 1 \mu \mathrm{M} p \mathrm{NP} \\
5 \% \text { of total activity }\end{array}$ & $<4 \mu \mathrm{M} p N P^{b}$ \\
\hline $\begin{array}{l}\operatorname{TrCel7A} \text { core, } 30^{\circ} \mathrm{C} \\
\text { pNP-lac (PASC) }\end{array}$ & $\begin{array}{l}6 \pm 1 \mu \mathrm{M} p \mathrm{NP} \\
12 \% \text { of total activity }\end{array}$ & $<4 \mu \mathrm{M} p N \mathrm{P}^{\mathrm{b}}$ & $<4 \mu \mathrm{M} p \mathrm{NP}^{\mathrm{b}}$ \\
\hline $\begin{array}{l}\operatorname{TrCel7A}, 30^{\circ} \mathrm{C} \\
\text { pNP-lac (PASC) }\end{array}$ & $<4 \mu \mathrm{M} p N P^{\mathrm{b}}$ & $<4 \mu \mathrm{M}^{\mathrm{b}}$ & $<4 \mu \mathrm{M} p \mathrm{NP}^{\mathrm{b}}$ \\
\hline
\end{tabular}

PASC = phosphoric acid swollen cellulose; $p N P=$ para-nitrophenyl; $p$ NP-lac = para-nitrophenyl- $\beta$-D-lacoside; TrCel7A = cellobiohydrolase I; XOS = xylan oligosaccharide. The percentages were calculated on the basis of the total $p N P$ activity shown in Table 3 . The deviations are the standard deviations of five independent experiments. ${ }^{\mathrm{a}}$ The $K_{\mathrm{i}}$ for cellobiose in the $p$ NP-lac assay is $20 \mu \mathrm{M}$, which is exceeded here. The activities are underestimated. ${ }^{\mathrm{b}}$ The detected absorbance changes were below 0.02 absThe activities were too low for reliable quantification.

its sensitivity to inhibition by XOSs. As the location equilibrium is shifted towards the insoluble substrate, the sensitivity to XOS inactivation of $\operatorname{TrCel7A}$ decreases.

The results of our ITC experiments (Table 2) show that increasing the chain length of XOS is the main factor influencing binding affinity (Figure 4). The CBM seems not to interact with XOS, as the binding constant does not increase when the CBM is present. Interestingly, the binding of XOS observed by ITC also influenced the activity of $\operatorname{TrCel7A}$ on PASC, but to a certain extent PASC and XOS compete for binding. The activity data also confirmed the ITC binding data regarding the effect of the chain length, because high XOS reduced the activity of $\operatorname{TrCel7A}$ more than low XOS did. Additionally, temperature influenced the competition between XOS and PASC. At $30^{\circ} \mathrm{C}$, the productive binding of $\operatorname{TrCel7A}$ to PASC was greater. At $50^{\circ} \mathrm{C}$, the equilibrium shifted slightly towards the unproductive binding of XOS. On the basis of the measured binding enthalpies and the van 't Hoff equation, we predict that
A

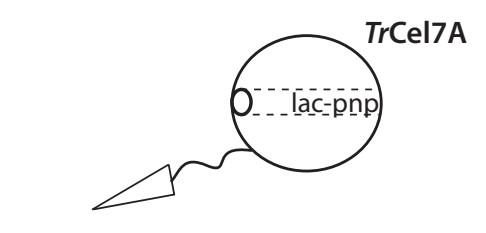

pNP-lac $\underset{\text { reference }}{\stackrel{\text { TrCel7A }}{\longrightarrow}}$ lac + pNP

B

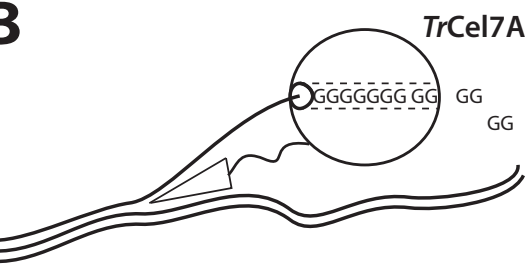

PASC $\underset{\text { reference }}{\stackrel{\text { TrCel7A }}{\longrightarrow}}$ cellobiose
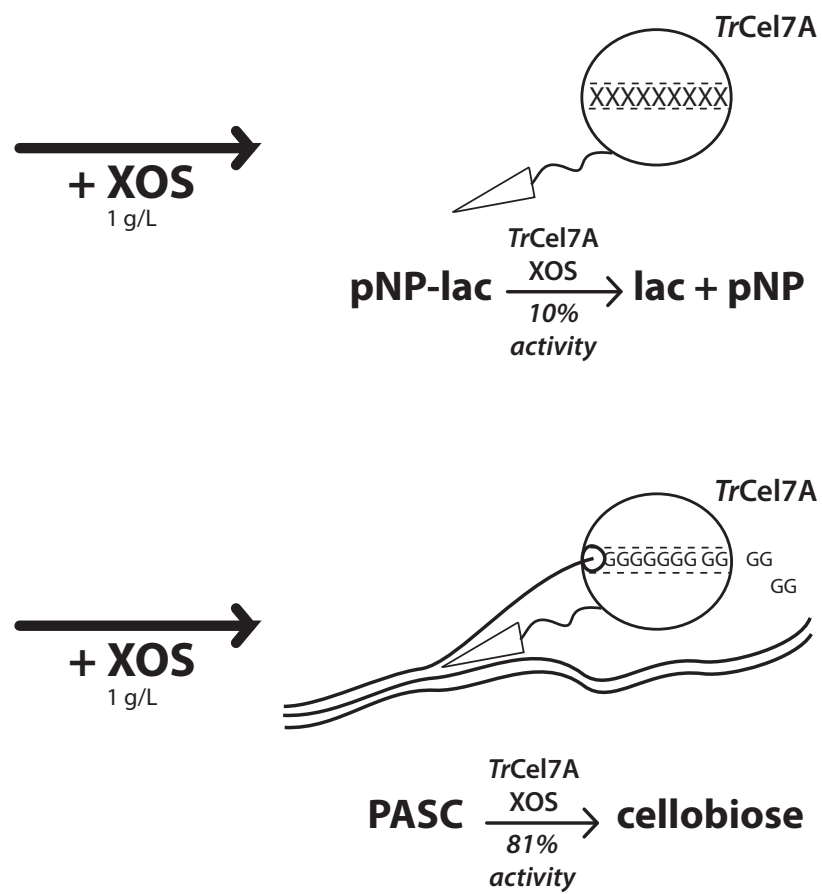

Figure 4 Cartoon representing the inhibition mechanism of xylan oligosaccharide with different substrates. (A) Xylan oligosaccharide

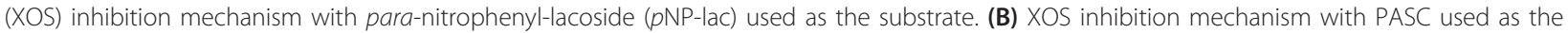
substrate. In both cases, the activity of cellobiohydrolase I (TrCel7A) was decreased by the presence of XOS. The active site was most likely occupied by unproductively bound XOS, preventing the substrate from entering the active site tunnel. The degree of inhibition is dependent on the ratio of the binding affinities between the substrate and the inhibitor. 
the binding constant for the XOS will decrease by about $40 \%$ when the temperature is increased from $30^{\circ} \mathrm{C}$ to $50^{\circ} \mathrm{C}$. However, changes in the affinity to cellulose are unknown, and at this point we can only speculate about the balance between the individual binding constants at higher temperatures.

XOSs are linear oligosaccharides with the same type of $\beta(1 \rightarrow 4)$ bond as cellulose. The structural similarity between XOSs and cellulose may make it possible to fit XOS sterically into the active site of $\operatorname{TrCel7A}$. The results of our ITC-binding experiments reveal that increasing the chain length of XOS promotes binding to $\operatorname{TrCel7A}$. The highest binding constants were found for XOS, which approximately matched the length of the $\operatorname{TrCel7A}$ active site (Table 1). In our opinion, it is plausible that XOS could be a competitive inhibitor of $\operatorname{TrCel7A}$ by occupying the active site in place of the substrate. This interpretation is in accord with both the absence of a CBM effect in the binding studies and the presence of such an effect for PASC hydrolysis, but further (structural) studies are needed to unequivocally confirm this hypothesis.

In principle, all active cellobiose-releasing complexes are formed with $\operatorname{TrCel7A}$ recruited from the small free pool of enzyme in solution; therefore, XOS inhibition can play a major role in reducing $\operatorname{TrCel7A}$ activity. This study clearly shows that a higher incubation temperature of $50^{\circ} \mathrm{C}$ increases the XOS inactivation of $\operatorname{TrCel7A}$.

\section{Conclusions}

In biomass hydrolysis experiments, the addition of xylanases and/or xylosidases increases the overall yield of glucose and xylose $[4,7,22,23]$. The observed synergy between xylanases and cellulases can at least partly be explained by the offset of cellulase inhibition as XOS is hydrolysed to low DP, which does not bind strongly to the active site of cellulose. It remains to be discovered whether this is only the effect of the addition of xylanases or whether there are other substrate-related effects, too.

\section{Methods}

\section{Xylan oligosaccharides}

Mixed and pure XOSs were produced as described by Baumann et al. [24]. Monodisperse xylotriose to xyloheptaose was obtained in 100-mg amounts, and mixed pools were obtained up to xylodecaose as described in Table 3. High XOS and low XOS were separated by ethanol precipitation (4:1) of high XOS from a solution of mixed XOS $(0.5 \mathrm{~L}$ at $14 \mathrm{~g} / \mathrm{L}$ concentration) in 50 $\mathrm{mM}$ sodium acetate, $\mathrm{pH}$ 5.0. The fine precipitate (high $\mathrm{XOS}$ ) was separated on a glass fibre filter and dissolved in water. After freeze-drying this solution, $2.1 \mathrm{~g}$ of low XOS and $4.6 \mathrm{~g}$ of high XOS were obtained. Both fractions were analysed by HPAEC-PAD (Figure 1). We found that low XOS contained saccharides from xylobiose to xylose $_{11}$ with $80 \%$ of the relative peak area between xylobiose and xylopentose, whereas high XOS contained saccharides from xylobiose to $\mathrm{xyl}_{18}$ with $80 \%$ of the relative peak area between xylotetraose and (xyl) 12. The average molecular mass values of low XOS and high XOS were calculated as 4.0 and 8.1 xylose units, respectively, after the relative peak areas had been determined.

\section{Enzymes}

$\operatorname{TrCel7A}$ core was produced by site-directed mutagenesis of a $\operatorname{TrCel7A}$ sequence [UniProtKB:P62694]. The protein sequence of the catalytic domain used was the same sequence as that of $\operatorname{Tr}$ Cel7A but truncated by the carboxy-terminal CBM and the linker sequence. The mature $\operatorname{TrCel7A}$ core contained the first 436 amino acids after the signal peptides (17 amino acids). $\operatorname{TrCel7A}$ [UniProtKB:P62694] and TrCel7A core were both produced heterologously in Aspergillus oryzae by Novozymes A/S (Bagsværd, Denmark) according to patent WO/2000/039322 and were purified as described by Praestgaard et al. [9].

\section{ITC binding}

The binding affinity of $\operatorname{Tr}$ Cel7A and $\operatorname{Tr}$ Cel7A core was measured at $30^{\circ} \mathrm{C}$ in an $\mathrm{iTC}_{200}$ power-compensated isothermal titration calorimeter (MicroCal/GE Healthcare, Northampton, MA, USA) with a cell volume of $200 \mu \mathrm{l}$ and by using an injector equipped with a $40-\mu \mathrm{l}$ syringe. All binding experiments were carried out at $30^{\circ} \mathrm{C}$ with $1,000 \mathrm{rpm}$ stirring. In a typical binding experiment, the cell was filled with $40 \mu \mathrm{M}$ cellobiohydrolase, and pure XOS $(1.25 \mathrm{mM})$ or pools of mixed oligosaccharides (low XOS $5 \mathrm{~g} / \mathrm{L}$ about $8.4 \mathrm{mM}$ or high XOS $5 \mathrm{~g} / \mathrm{L}$ about 4.4 $\mathrm{mM}$ ) were injected according to the following protocol: initial equilibration for 16 minutes, then nine injections of $1 \mu \mathrm{l}$ after 150 seconds, followed by fifteen injections of $2 \mu \mathrm{l}$. Data were analysed using Origin 7.0 software (OriginLab, Northampton, MA, USA) with the add-on provided by MicroCal/GE Healthcare.

\section{Enzyme activity}

Cellobiohydrolase activity was measured as cellobiose release from $1 \mathrm{~g} / \mathrm{L} \mathrm{PASC}$ at $50^{\circ} \mathrm{C}$ or $30^{\circ} \mathrm{C}$ with $300 \mathrm{rpm}$ shaking in an Eppendorf heating block. TrCel7 A and $\operatorname{TrCel7A}$ core amounts were adjusted to release $100 \mu \mathrm{M}$ or $127 \mu \mathrm{M} p \mathrm{NP}$ from $p \mathrm{NP}$-lac when incubated at $50^{\circ} \mathrm{C}$ for one hour. After one hour of incubation, PASC was removed by short centrifugation for 20 seconds in a tabletop centrifuge. An aliquot of the supernatant $(0.5$ $\mathrm{ml}$ ) was removed and incubated at $99^{\circ} \mathrm{C}$ for 20 minutes at $300 \mathrm{rpm}$ in an Eppendorf heating block to inactivate 
the cellobiohydrolase. We analysed $10 \mu \mathrm{l}$ of the supernatant by HPAEC-PAD. XOSs $(200 \mu \mathrm{l})$ were added to a final concentration of $1 \mathrm{~g} / \mathrm{L}$, which is approximately equivalent to $1.7 \mathrm{mM}$ low XOS or $0.9 \mathrm{mM}$ high XOS. The amount of free cellobiohydrolase was quantified as $p$ NP release from $p$ NP-lac as described by Jalak and Väljamäe [16].

\section{Product inhibition of TrCel7A}

A simple quantification of $\operatorname{Tr}$ Cel7A activity is hindered by several parameters. $\operatorname{Tr}$ Cel7A is product-inhibited by cellobiose. In the hydrolysis of bacterial cellulose, the product inhibition by cellobiose was measured by Gruno et al. [21] as $K_{\mathrm{i}}$ approximately $1.5 \mathrm{mM}[14,21]$. Thus we chose to limit the product inhibition by restricting the amount of produced cellobiose to a maximum of $1 \mathrm{mM}$. The values that we obtained for $p$ NP-lac activity are most likely underestimates, since the $K_{\mathrm{i}}$ for cellobiose is $20 \mu \mathrm{M}$ for the hydrolysis of $p$ NP-lac [20], and the cellobiose concentration was higher in most of our experiments.

\section{Abbreviations}

$k_{\text {cat }}$ : catalytic rate constant; $K_{\mathrm{i}}$ : inhibition constant; $K$ : binding constant

\section{Acknowledgements}

We thank Dr Katja Salomon Johansen at Novozymes for the enzyme samples of TrCel7A. This work was supported by The Danish Council for Strategic Research (grants 09-063210 and 2104-07-0028) and by the US Department of Energy (grant DE-FC36-08G018080).

\section{Author details}

${ }^{1}$ Research Unit for Biomaterials, Roskilde University, NSM, Universitetsvej 1, DK-4000, Roskilde, Denmark. ${ }^{2}$ Novozymes A/S, Krogshøjvej 36, DK-2880, Bagsværd, Denmark.

\section{Authors' contributions}

MJB designed, planned and conducted the study, and drafted the manuscript. KB provided the enzymes and reviewed the manuscript. PW participated in the critical discussion of the results and finalized the manuscript. All authors read and approved the final manuscript.

\section{Competing interests}

MJB and KB are employed by Novozymes A/S (Bagsværd, Denmark), which is a major enzyme producer. PW declares no competing interests.

Received: 8 July 2011 Accepted: 31 October 2011

Published: 31 October 2011

\section{References}

1. Jørgensen $\mathrm{H}$, Kristensen JB, Felby C: Enzymatic conversion of lignocellulose into fermentable sugars: challenges and opportunities. Biofuels Bioproducts Biorefining 2007, 1:119-134.

2. Zhang YHP, Lynd LR: Toward an aggregated understanding of enzymatic hydrolysis of cellulose: noncomplexed cellulase systems. Biotechnol Bioeng 2004, 88:797-824.

3. Mosier N, Wyman C, Dale B, Elander R, Lee YY, Holtzapple M, Ladisch M: Features of promising technologies for pretreatment of lignocellulosic biomass. Bioresour Technol 2005, 96:673-686.

4. Kumar R, Wyman CE: Effect of enzyme supplementation at moderate cellulase loadings on initial glucose and xylose release from corn stover solids pretreated by leading technologies. Biotechnol Bioeng 2009, 102:457-467.
5. Qing Q, Wyman CE: Hydrolysis of different chain length xylooliogmers by cellulase and hemicellulase. Bioresour Technol 2011, 102:1359-1366.

6. Qing Q, Yang B, Wyman CE: Xylooligomers are strong inhibitors of cellulose hydrolysis by enzymes. Bioresour Technol 2010, 101:9624-9630

7. Qing Q, Wyman C: Supplementation with xylanase and $\beta$-xylosidase to reduce xylo-oligomer and xylan inhibition of enzymatic hydrolysis of cellulose and pretreated corn stover. Biotechnol Biofuels 2011, 4:18.

8. Kipper K, Väljamäe P, Johansson G: Processive action of cellobiohydrolase Cel7A from Trichoderma reesei is revealed as 'burst' kinetics on fluorescent polymeric model substrates. Biochem J 2005, 385:527-535.

9. Praestgaard E, Elmerdahl J, Murphy L, Nymand S, McFarland KC, Borch K, Westh P: A kinetic model for the burst phase of processive cellulases. FEBS J 2011, 278:1547-1560.

10. Väljamäe P, Kipper K, Pettersson G, Johansson G: Synergistic cellulose hydrolysis can be described in terms of fractal-like kinetics. Biotechnol Bioeng 2003, 84:254-257.

11. Kurasin M, Väljamäe P: Processivity of cellobiohydrolases is limited by the substrate. J Biol Chem 2011, 286:169-177.

12. Cantarel BL, Coutinho PM, Rancurel C, Bernard T, Lombard V, Henrissat B: The Carbohydrate-Active EnZymes database (CAZy): an expert resource for glycogenomics. Nucleic Acids Res 2009, 37 Database: D233-D238.

13. Divne C, Ståhlberg J, Reinikainen T, Ruohonen L, Pettersson G, Knowles JKC, Teeri TT, Jones TA: The 3-dimensional crystal structure of the catalytic core of cellobiohydrolase-1 from Trichoderma reesei. Science 1994, 265:524-528.

14. von Ossowski I, Ståhlberg J, Koivula A, Piens K, Becker D, Boer H, Harle R, Harris M, Divne C, Mahdi S, Zhao Y, Driguez H, Claeyssens M, Sinnott ML, Teeri TT: Engineering the exo-loop of Trichoderma reesei cellobiohydrolase, Cel7A: a comparison with Phanerochaete chrysosporium Cel7D. J Mol Biol 2003, 333:817-829.

15. Deshpande MV, Eriksson KE, Pettersson LG: An assay for selective determination of exo-1,4,- $\beta$-glucanases in a mixture of cellulolytic enzymes. Anal Biochem 1984, 138:481-487.

16. Jalak J, Väljamäe $P$ : Mechanism of initial rapid rate retardation in cellobiohydrolase catalyzed cellulose hydrolysis. Biotechnol Bioeng 2010, 106:871-883.

17. Harnpicharnchai $P$, Champreda V, Sornlake W, Eurwilaichitr L: A thermotolerant $\beta$-glucosidase isolated from an endophytic fungi, Periconia sp., with a possible use for biomass conversion to sugars. Protein Expr Purif 2009, 67:61-69.

18. Yoon JJ, Kim KY, Cha CJ: Purification and characterization of thermostable $\beta$-glucosidase from the brown-rot basidiomycete Fomitopsis palustris grown on microcrystalline cellulose. J Microbio/ 2008, 46:51-55.

19. Zanoelo FF, Polizeli M, Terenzi HF, Jorge JA: $\beta$-glucosidase activity from the thermophilic fungus Scytalidium thermophilum is stimulated by glucose and xylose. FEMS Microbiol Lett 2004, 240:137-143.

20. Teeri $\Pi$ : Crystalline cellulose degradation: new insight into the function of cellobiohydrolases. Trends Biotechnol 1997, 15:160-167.

21. Gruno M, Väljamäe P, Pettersson G, Johansson G: Inhibition of the Trichoderma reesei cellulases by cellobiose is strongly dependent on the nature of the substrate. Biotechnol Bioeng 2004, 86:503-511.

22. Murashima K, Kosugi A, Doi RH: Synergistic effects on crystalline cellulose degradation between cellulosomal cellulases from Clostridium cellulovorans. J Bacteriol 2002, 184:5088-5095.

23. Selig MJ, Knoshaug EP, Adney WS, Himmel ME, Decker SR: Synergistic enhancement of cellobiohydrolase performance on pretreated corn stover by addition of xylanase and esterase activities. Bioresour Technol 2008, 99:4997-5005.

24. Baumann MJ, Murphy L, Lei N, Krogh KB, Borch K, Westh P: Advantages of isothermal titration calorimetry for xylanase kinetics in comparison to chemical-reducing-end assays. Anal Biochem 410:19-26.

\section{doi:10.1186/1754-6834-4-45}

Cite this article as: Baumann et al: Xylan oligosaccharides and cellobiohydrolase I (TrCel7A) interaction and effect on activity. Biotechnology for Biofuels 2011 4:45 